NIST GCR 15-984

\title{
White Paper on Fire Behavior of Steel Structures
}

\author{
Maria Garlock \\ Princeton University, USA \\ Joël Kruppa \\ Ismans Engineering School, France \\ Guo-Qiang Li \\ Tongji University, China
}

Bin Zhao

Centre Technique Industriel de Construction Métallique (CTICM), France

This publication is available free of charge from:

https://doi.org/10.6028/NIST.GCR.15-984

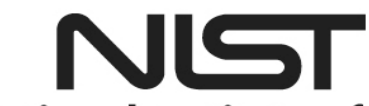

National Institute of Standards and Technology

U.S. Department of Commerce 


\title{
White Paper on Fire Behavior of Steel Structures
}

\author{
Prepared for \\ U.S. Department of Commerce \\ Engineering Laboratory \\ National Institute of Standards and Technology \\ Gaithersburg, MD 20899-8660
}

By

Maria Garlock

Princeton University, USA

Joël Kruppa

Ismans Engineering School, France

Guo-Qiang Li

Tongji University, China

Bin Zhao

Centre Technique Industriel de Construction Métallique (CTICM), France

This publication is available free of charge from:

https://doi.org/10.6028/NIST.GCR.15-984

September 2014

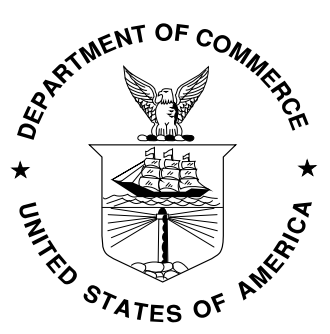

U.S. Department of Commerce Penny Pritzker, Secretary

National Institute of Standards and Technology Willie May, Acting Under Secretary of Commerce for Standards and Technology and Acting Director 
This publication is available free of charge from: https://doi.org/10.6028/NIST.GCR.15-984

\section{Notice}

This report was prepared for the Engineering Laboratory of the National Institute of Standards and Technology by Applied Research Associates (ARA) under contract number SB1341-12-CQ-0014/13496. The statements and conclusions contained in this report are those of the authors (subcontractors for ARA) and do not necessarily reflect the views of the National Institute of Standards and Technology or the Engineering Laboratory. 


\section{WHITE PAPER}

\section{FIRE BEHAVIOR OF STEEL STRUCTURES}

A report for the National Institute of Standards and Technology

by

Maria Garlock, Princeton University, USA

Joël Kruppa, Ismans Engineering School, France

Guo-Qiang Li, Tongji University, China

Bin Zhao, CTICM, France

Final Report

June 2014 
This publication is available free of charge from: https://doi.org/10.6028/NIST.GCR.15-984 


\section{Contents}

1 Introduction and Background Information ....................................................................................... 1

2 State-of-the-Art in Fire-Structure Performance-Based Design, Modelling, and Experiments....2

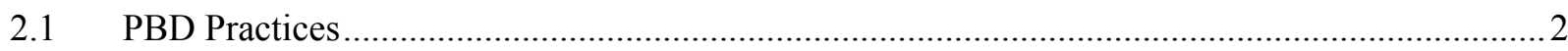

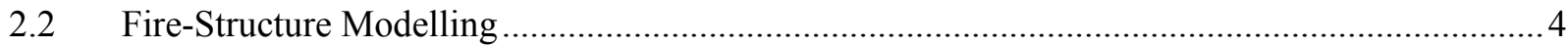

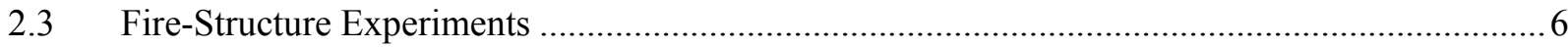

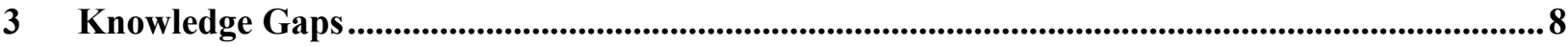

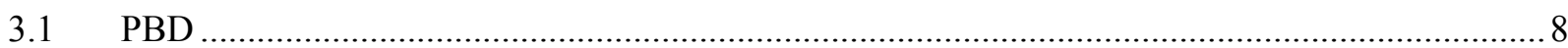

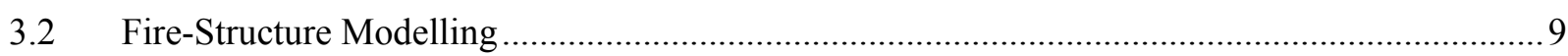

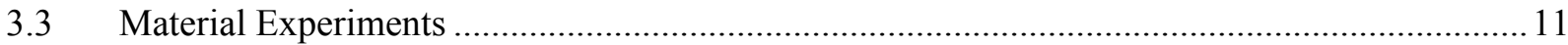

4 Topics 1 and 2: Identify and Prioritize Large-Scale Experimental Needs in Order of Importance to PBD...................................................................................................................................11

5 Topic 3: Needed Research in a Timeline .........................................................................................13

6 Topic 4: Laboratory Facilities Available to Address Each Need ..............................................13

7 Topic 5: Potential Collaborators and Sponsors for Each Need ......................................................14

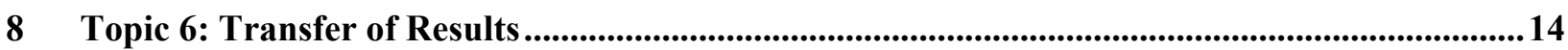

9 Topic 7: Means to Review Progress and Exchange Information .................................................15

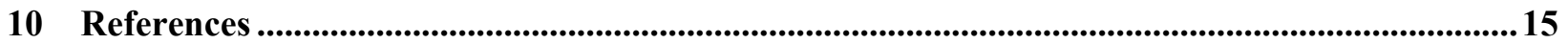




\section{Introduction and Background Information}

The National Institute of Standards and Technology (NIST) conducted its building and fire safety investigation of the World Trade Center (WTC) disaster of September 11, 2001, under the authority of the National Construction Safety Team (NCST) Act. The NCST's Final Report includes 30 recommendations that address (1) specific improvements to building standards, codes, and practices; (2) changes to, or the establishment of, evacuation and emergency response procedures; and, (3) research and other appropriate actions needed to help prevent inappropriate future building failures in fire situation. As part of NIST's plan to implement the report's recommendations regarding new methods for fire resistance design of structures, NIST intends to develop an international research and development $(\mathrm{R} \& \mathrm{D})$ roadmap on the fire resistance of structures. To support the development of the roadmap, NIST held a workshop on largescale experimental and modelling fire resistance of structures research needs. NIST has commissioned three White Papers, to be used as the basis for technical discussions at the workshop. This effort will provide input for prioritizing and coordinating international research activities and facilitate the development of advanced validated tools for the performance-based engineering fire resistant design of structures.

This report dealing with steel structures is one of these White Papers. By steel structures it is meant both pure steel structures and composite structures in which the steel is directly exposed to fire and the concrete contributes to the loadbearing capacity of the structure. Examples of composite structures include concrete-filled steel tube column and steel beam coupled with concrete slab.

This white paper presents the state-of-the-art of large-scale experiments, modeling, and performance-based design efforts in fire behavior of steel structures. In addition, this paper discusses the seven "Topics" listed below.

- Topic 1. Research and development needs for large-scale experiments on fire resistance of structures to support performance-based engineering and structurefire model validation;

- Topic 2. Prioritization of research and development needs in order of importance to performance-based engineering;

- Topic 3. Phasing the needed research in terms of a timeline;

- Topic 4. Most appropriate international laboratory facilities available to address each need;

- Topic 5. Potential collaborators and sponsors;

- Topic 6. Primary means to transfer the results from each series of tests to industry through specific national and international standards, predictive tools for use in practice, and comprehensive research reports; and

- Topic 7. Means for the coalition of international partners to review progress and exchange information on a regular basis. 
This White Paper draws upon some information obtained from reports recently published, such as:

- "Structures in Fire: State of the Art, Research and Training Needs" published in 2011 by Fire Technology [1]. In this paper, the state of the art is presented for (1) modeling and predictions, (2) experiments, (3) materials. It covers all materials, not just steel, and the paper is based on the input of many researchers in this field who attended a 2007 workshop, where the participants identified top 10 research and training needs.

- $\quad$ "Structural Fire Resistance Experimental Research - Priority Needs of U.S. Industry" released in 2012 by NFPA Foundation [2].

- Needs to achieve improved fire protection as regards the implementation and development of the EN Eurocodes", published in 2008 by the European Commission [3].

- "State-of-the-art and Suggestion of Research on Fire-Resistance of Structures", Report on Research Development Strategy for 2011 2020 by Natural Science Foundation of China (NSFC) in 2010 [4].

It also includes new researches and needs in fire-structure interactions that have been identified since these reports were published.

\section{State-of-the-Art in Fire-Structure Performance-Based Design, Modelling, and Experiments}

Historically, the fire resistance of building structures (or other civil work) was assessed to a large extent by performing tests on isolated structural elements (beams, columns, slabs ...) under standard fires (e.g. ISO 834 [5] or ASTM E 119[6]). Thereafter, on the basis of these tests, simple calculation methods for determining fire resistive ratings for steel structures were derived. During last two or three decades, a number of numerical simulation models were developed that enable us to predict the complete history of structural response subjected to any kind of fire. These simulations are an important tool for performance-based design.

The current state of art for the behavior of steel structures includes three main topics: performance-based design (PBD) practices, fire-structure modeling, and fire-structure experiments. Each topic is developed in the sections that follow.

\subsection{PBD Practices}

The majority of fire design for structures is based on the "prescriptive approach", where the code states how the building has to be constructed and, when necessary protected, under standard fire; whereas in performance-based design (PBD) the code states how the building is to perform to meet fire safety objectives under various realistic fire conditions. In most countries, designers rely on a prescriptive approach, which is based on the results of standard fire tests on isolated structural specimens [7], or even simple calculation methods, to determine the required fire protection on steel components of buildings (e.g., ASCE/SFPE29, IBC and Structural Eurocodes [15, 16, 38, 73]). However, these conventional approaches do not accurately reflect a real compartment fire timetemperature relationship nor the real behavior of an entire structure subjected to a non- 
uniform temperature distribution. Therefore, prescriptive building codes do not properly cover the real structural performance of a building in real fire situations.

The performance-based design approach [8,9] allows the designer to consider real fire scenarios [10] and the effects of the resulting fires on the structure as a whole (as opposed to individual member behavior not considering the "real" boundary conditions). This approach is able to have safer and more economical choices and also to give the designer more freedom to express the architectural or industrial needs due to the activity within the building or the civil work. However, an appropriate use of PBD requires education and judgment as related to structure-fire interaction, and knowledge in structure-fire response modeling.

Considering that a performance-based fire design of a steel structure is a process as reported in the CIB publication 269 [11] or in the ISO/TS 24679 [12, 13], we have to recognize that calculation of only the critical steel temperature or the necessary thickness of fire protection material to fulfil required fire duration under standard fire (as done by the simple calculation methods like those given within the fire parts of Structural Eurocodes [14 - 16] or ASCE/SPFE29) cannot be considered as a PBD approach; it is only a way of replacing fire tests by using simple calculation formulae to predict fire resistance of steel structural members.

Generally, PBD approaches are based mainly on either advanced calculation models (numerical simulations) or analytical formulas. However, in some cases, experimental results have to be used in cases where calculation methods are not accurate enough or input data for calculation are not available.

The successful implementation of PBD into design practice will be met with the following challenges in the field of structure-fire interaction: (1) availability of accurate (simple and when necessary more sophisticated) predictive tools for practice, (2) educating the structural engineer and/or the fire protection engineer, (3) growing the knowledge. These challenges are described in more detail throughout the report.

All PBD approaches for structure-fire design to date are based on a 'first-generation' approach that uses deterministic values for the variables (e.g., high temperature material properties). However, there are inherent uncertainties in these variables. A reliability performance-based approach, which is a 'second-generation' PBD, uses a probability distribution for the variables with uncertainties. Such an approach "improve[s] ... risk decision-making through assessment and design methods that have a strong scientific basis and that express options in terms that enable stakeholders to make informed decisions."'[17]. This is a new and growing area of research within the broader area of structure-fire interaction [e.g., $18-22$ ].

Multi-hazard design for fire is another complex but necessary approach to PBD. As a single event, fire is already considered as one of primary hazards for buildings and civil works. Fire could become particularly dangerous if it is caused by another hazard (a secondary event). As shown in the terrorist attacks on the World Trade Center on Sept. 11, 2001, steel buildings might be able to survive a sudden impact but subsequent fires might make the buildings unable to carry the weight of the structure leading to a failure. 
The events of Sept. 11 made the structural engineering profession aware that more research was needed on the response of structures to fire and since then advances in the field have been made; the vast majority of this research was applied to fire as a primary event, where the initial condition of the structure was undamaged. Fire as a secondary event, where significant structural damage exists before could happen after impact or earthquake, but the more frequent situation occurs in the case of a blast or explosion (which is more frequently happening in chemical factories). In such instances, a fire begins when the initial condition of the structure is in a damaged state, and the building could lose beams, columns, or be subject to permanent plastic deformations. Within this context of multi-hazard, some research has been developed for fire following blast and fire following earthquake [23 - 32].

\subsection{Fire-Structure Modelling}

There are essentially three components to model structures in fire: the fire model, the heat transfer model, and the structural model. A structure-fire interaction model must consider all three components; typically, all three are considered to be weakly coupled (one-way coupling). This means that the results of the former is transferred to the later as its input data in one direction only (in the direction listed above). There are no comprehensive tools to avoid this single direction communication. The deformation of the structure could have an impact on the capability of the fire separating element to limit the fire propagation from one compartment to another. Structural deformations will thus have some influence on the thermal heat flux received by structural members or the change in the fire development model, for example if a portion of a floor/roof collapses, so this has to be considered in the fire model and/or the heat transfer model.

Each of the above mentioned model components can be simple or complex. For example, for a small post flash-over compartment fire, the heat transfer model can be either 1dimensional (1-D) or 2-dimensional (2-D) with even and uneven temperature through the cross-section of the element being examined. When considering a localized fire within a large compartment, it can be a 3-D model with temperature varying along the length as well as through the cross-section of the structural element. Similarly, the structural model can be 1-D, 2-D or 3-D, and it can use bar elements, beam elements or more complex shell elements. The modeler needs to consider the level of details in the model and suitability on the structural performance that needs to be captured. The "cost" of the analysis must also be considered: the more detailed, the more computationally expensive it is in terms of setup and run-time.

Furthermore, the modeler needs to consider that significant uncertainty exists in the input, including the fire load and mechanical loads, the geometry of the structure and its constitutive elements, the thermo-mechanical material properties, which need to be considered when interpreting the accuracy of the structural analysis results. A parametric or sensitivity analysis can be employed to at least partially evaluate the range of feasible predicted outcomes.

Current practices in fire-structure modelling can be divided into the following categories: (a) finite element tools (computer modeling), (b) analytical formulas, and (c) constitutive materials and uncertainties. Each of these subjects is described in detail below. 


\section{(a) Finite element tools (computer modeling)}

In the past 15 years, many advances have occurred in software dedicated to structures in fire [e.g., 33, 34]. Other general purpose and commercially available software can also be used for structure-fire modeling. [e.g., 35 - 37]. These programs are quite complex to use for everyday fire applications but when used by trained practitioners they provide a fair assessment of the reality.

Many limitations exist for modeling structures in fire in a seamless, efficient, and appropriate way. For example, the links between the fire, thermal, and structural models are not yet advanced enough. If one wants to do a 3-D computational fluid dynamics model of the fire, it is generally difficult to transfer that data to the heat transfer model in a seamless and efficient manner. However some research projects were performed in Europe on this topic [39] as well as in other countries [40, 41] The same difficulty exists if one wants to transfer data from a 3-D heat transfer model to a 3-D structural model (where typically the heat transfer model will use brick elements and the structural model will use commonly beam or shell elements). In addition, the complete analysis is typically one-way coupled as described previously.

\section{(b) Analytical formulas}

As an alternative to computational tools, simple calculations can be performed using closed-form solutions that consider equilibrium and compatibility. These closed-form solutions can provide a reasonable approximation of the structure-fire response, and they can also be used to provide some level of validation for the more complex computational solutions. For example, the fire development model can be approximated by parametric curves. The heat transfer model in steel sections with relatively thin plates can be done with a spreadsheet using a lumped mass approach that assumes the temperature of the steel is uniform or even with a simple formula developed for predicting the temperature rise of a steel component under fire curve [42]. The structural model can be a beamelement with the appropriate boundary conditions (which are assumed to be unchanged during the fire) that represent the surrounding structure.

Analytical formulas for simple elements under uniform temperature for standard fire have been developed for beams and columns and composite slabs [15, 16, 42, 43]. Both protected and unprotected steel are covered by these formulas to the extent the proper thermal properties of the protection systems are known [15, 43].

In addition, analytical formulas for assessing loadbearing capacity have been developed for beams and columns with thermal gradients [15, 44 - 50], for composite elements such as concrete filled hollow steel section or I-column or beam sections with concrete between the flanges $[16,51]$ and also for beam-column connections [89]. On the other hand, an analytical calculation method was developed for structural elements located outside the burning building and subjected to heat coming from external flames passing through windows $[15,16,52]$.

Limited research is available that recommends formulas that consider the structural response of elements under fire as part of a larger structural system. For example, a proposal is made for closed-form approximations of the maximum axial force in a beam 
considering local buckling of the beam that will develop due to the adjacent structure [53]. More recently, several projects have been conducted in the world, which have led to various analytical formulas for predicting the load-bearing capacity of steel and concrete composite floor systems subjected to both standard fire and real compartment fire conditions and behaving under membrane action [54 - 57].

\section{(c) Constitutive materials}

High temperature thermal and mechanical material properties of steel are available [15, 58, 59]. Most are for steels used in buildings but recent studies have been made on steels used in bridges such as A709 and A588 weathering steel [60, 61]. However some uncertainties still exist on these thermo-physical properties. It is not clear how this uncertainty/variability affects the structural response as a whole. Probabilistic approaches are able to quantify these material property uncertainties.

\subsection{Fire-Structure Experiments}

The discussion about fire-structure experiments is divided into the following sections: (a) standard fire tests on structural elements, (b) structural system tests, (c) material tests, and (d) hybrid testing methods.

\section{(a) Standard tests on structural elements}

Structural element tests are usually performed within a prescriptive regulation. Tests are conducted on individual structural elements or assemblies, such as beams, columns, floors or walls, of specific dimensions to standard fire exposure in a specially designed fire test furnace. Test procedures, including fire (time-temperature) curves, are specified in standards such as ASTM E119 [6], ISO 834 [5], and EN 1363 [62].

Within this section, tests on subassemblies such as girders with slabs or roof can also be considered. In North America, steel columns or subassemblies are generally not loaded during the tests; rather an alternative test procedure is employed whereby the end point (failure) criterion is based on a critical limiting temperature in structural steel.

There are many drawbacks with the structural element / subassembly tests under standard fire procedure described above, the most important being that such tests do not account for real fire scenarios (and no decay phase), structural interactions with adjacent framing, realistic load levels and restraint conditions. Further, some current test methods and their acceptance criteria do not give due consideration to various limit states, such as strength, stability, deflection, and rate of deflection for assembly failure.

\section{(b) Structural system tests}

There has been only a very limited number of fire experiments that have considered the full structural system for evaluating global response of structures. A few tests on portal frames were conducted in the 70 's to 90 's. Full-scale fire test of 4 story car park ( $20 \mathrm{~m} \mathrm{x}$ 30m) was conducted in Japan in 1993 [87, 88]. In France, a test on a steel structure car park of $30 \mathrm{~m} \times 15 \mathrm{~m}$, under real car fires, was performed in 2001 [63-65] and a test on a steel warehouse of $48 \mathrm{~m} \times 32 \mathrm{~m}$ and $12 \mathrm{~m}$ height subjected to a fire with 310 tonnes of wood over a surface of $24 \mathrm{~m} \times 32 \mathrm{~m}$, in 2008 [66]. In China, full-scale fire tests were 
conducted on two-story two-bay composite steel frames $[67,68]$. However, the most notable and significant research in full structure fire experiments was undertaken in the last decades by the Building Research Establishment (BRE) in the U.K, which conducted a series of full-scale fire tests in the Large Building Test Facility (LBTF) at Cardington [69 - 71]. The tests on multi-story steel and concrete buildings provided unique and valuable response data regarding the behaviour of both structural and non-structural elements within a real compartment subjected to real fires.

Amongst the unexpected damage in the first Cardington tests was the tension failure of the steel connections during the cooling phase of the fire. Several experiments have been done on various types of steel connections to illustrate connection vulnerability and means to improve their performance in fire [90 - 95].

\section{(c) Material tests}

In addition to fire tests on structural elements and systems, the temperature dependent properties of steel materials (both thermal and mechanical) are critically important for establishing an understanding of the fire-response of structures. The literature review indicates that the high temperature properties of steel (structural, reinforcing steel) are available (e.g. [72, 59]). However, there is large variability in similar data obtained from different sources. This high variation in the reported high-temperature properties of steel can be attributed to lack of standardized test methods to test high-temperature properties, and no standardized equipment to measure properties.

Regarding the capability of fire protection systems to provide an adequate protection to steel or composite structures, new test procedures were developed in Europe (see EN 13381- - $4,-5,-6 \&-8$ [74 - 76]) to ensure the protective material remain cohesive and coherent to its support, despite the deflection occurring at high temperature.

Also, some tests have been done on measuring the effectiveness of SFRM (Sprayed fireresistive material) adhesion to steel following large strains related to seismic loading [77, 78].

\section{(d) Hybrid testing methods}

Hybrid fire testing (HFT) considers the effects on a whole building, but only tests individual elements or subassemblies. Computer simulations of a full structure are made, from which an element or subassembly is tested. The computer-simulation of the full structure transfers data to the actuators that represent the forces imposed by the adjacent structure in the tests. HFT therefore simulates the fire performance of the whole building at a lower cost than full-scale testing, and with more reliable results than prescriptive testing. HFT offers the possibility of investigating various fire scenarios, using selected facilities for physical testing, and running the simulation analysis remotely at different locations anywhere in the world. This is a proven method for seismic testing and is recently being adopted for fire at NRC Canada and BAM Germany [79 - 82]. However, the accuracy of these tests depend on the accuracy of the numerical simulations. 


\section{Knowledge Gaps}

\subsection{PBD}

The knowledge gaps related to PBD are strongly tied to knowledge gaps in modeling and experiments as discussed in detail in the next two sections. The main PBD gaps are: (1) the discrepancy between a structural design made by prescriptive methods (considering isolated structural elements to fulfill fire resistance requirements based on the standard fire) and PBD (design of a complete structure taking into account actual fire risks), and (2) lack of knowledge in input data or calculation models leading to the need to refer to large or full scale tests results.

Regarding the discrepancy (item (1)), it is now more possible than before to develop a performance-based approach using design fire scenarios and computer code for analysis. In addition, sensitivity analysis on a large variety of buildings and activities provide guidelines for more realistic prescriptive requirements [83].

Regarding lack of knowledge (item (2)), for performance-based design it is necessary to know the relevant fire load during the life time and related heat release rate for different types of buildings and activities, as well as guidelines to select design fire scenarios. In addition, one needs to know fire development in various building configurations and strength or deformation design limits of structural components or systems in a fire. Of course, this matter is not a specific one for steel structures, but applicable to all structural types.

In addition, the current regulatory structure in many countries, such as the United States, does not foster performance-based design approaches. Although there are some published performance-based building codes (e.g. ICC), there is little infrastructure or tools to use them. This would include, at a minimum, agreed upon performance goals and

acceptable levels of risk. For widespread implementation of performance-based design approaches, such an approach must be codified into recognized national standards. These standards generally do not exist, although some are under development. Currently, ASCE's Fire Protection committee submitted a proposal to include PBD for fire in ASCE-7. While it is still under consideration, one of the main concerns by reviewers of the profession is that there is no single comprehensive source (e.g., a book or report) to guide an engineer through the process of PBD.

And finally, PBD is an engineered approach, yet there is no clearly defined role for the structural engineer or the fire protection engineer in the design of structures for fire. And the structural engineer is typically not educated with knowledge on fire development or fire-structure interaction, and the fire protection engineer is not educated in structural behavior. Typically the architect has responsibility for the fire safety in building design. The architect may call on a fire protection engineer but recognition for the role for the structural engineer will be necessary for widespread implementation of PBD. Certainly, the fire engineer must also become an active participant in the creative, trans-disciplinary process of design. While this is not a knowledge gap, it is an important challenge to recognize. 


\subsection{Fire-Structure Modelling}

The numerical models that are currently being used for predicting the response of structures under fire loading are complex and there is a clear need to validate the use of these models with experimental data. There is a need for having a database on component test results and on the other hand for performing full-scale/real-scale testing of structures under fire loading to improve the capability of these numerical models.

\section{(a) Gaps in finite element tools (computer modelling)}

The first step in structural fire response modeling is to identify the thermal loads on a structure due to fire. The thermal loads on a structure are closely coupled to the radiative and convective heating from the fires to the structure. Although some research results are already available, development of more appropriate interfaces that couple the fire dynamics to the thermal response of a structure and link the thermal models to the structural models are a critical research need for having an efficient structural fire response modeling.

Gaps also exist due to the lack of interaction between the fire development and the structural response calculations. Within the main process commonly available, calculations are conducted in a "linear and one-way" manner (see Section 2.2 - State of art in fire structure modelling). There is no systematic process to take into account the fact that, with the large deformation of the structure, there is a change in the heating condition of structural elements, due to:

- the change in the distance or position between a structural element and the fire source (mainly for pre-flashover conditions), e.g. a bending beam becoming closer to the floor where the fire is located;

- possible damage of fire protection materials not able to remain coherent and cohesive to the thermally protected structural elements with large deformation; and

- possible cracks in non-loadbearing separating elements, created by large deformation of loadbearing element above, which lead to hot gases passing through and the change of heating conditions.

There is also a need to harmonize the definition of failure to be used with calculation results (mainly when calculating the deformation of the structure), which has to be different from the failure criteria used for testing, since these criteria were developed to safeguard the testing facilities and not to represent specific need within a burning building. Criteria need to be differentiated when considering, e.g., the robustness of the overall structure (taking into account concepts as fire-induced progressive damage and disproportionate damage) and the reparability.

In the context of a multi-hazard computational platform, software needs to advance to consider seamless multi-hazard simulation and modeling various uncertainties (MonteCarlo simulations). This needs to be done so that the simulation is efficient, numerically stable, accurate, and with robust algorithms that converge toward the correct solution. 
But to model uncertainties data are needed to form statistics for random variables, from which probability models can be developed.

Other gaps in FE modeling include:

- For steel and concrete composite structures, to take into account the bonding behavior at elevated temperatures between steel and concrete for reinforcing bars, steel tube, profile steel sheet and even I or H profile concreted between flanges, when the force transfer between these two materials is considered,

- To extend the knowledge in deformation capacity of various types of connections, (e.g., moment-rotation capacity at elevated temperatures),

- Improvements of calculation capabilities for geometric nonlinearity due to large structural deformation, for modeling rupture of connections and elements, as well as for considering the impact loading in case of collapse of upper floors.

\section{(b) Gaps in simple calculations methods (analytical formulas)}

Simple calculation methods for the following structural elements need to be developed:

- Composite columns partially exposed to fire (1, 2 or 3 faces),

- Column and beam with steel profiles encased in concrete,

- Connections within composite structure,

- Composite floors elements (composite slabs or composite beams) with fire above and with fire on both sides (under and above),

- Sub-assemblies (such as portal frame or part of it), and not only isolated structural elements.

\section{(c) Gaps on constitutive material models}

Improvement of knowledge needs to be achieved for following fields:

- Ductility limits for structural steel at high temperatures (given as $20 \%$ of strain in Eurocode $[15,16]$ regardless of the temperature), especially for high strength bolts and weld,

- Physical properties at elevated temperatures for high strength steel (yield stress above $500 \mathrm{MPa}$ ),

- Creep effects and the modeling techniques for advanced calculations, plus considering creep's influence on strain-stress relationship for simple calculation methods,

- Physical properties (stress-strain relationships, thermal properties ...) of various grades of structural steel, bolts and weld during cooling phases,

- Physical properties of fire protection materials (including reactive material such as intumescent paints), concerning thermal conductivity, specific heat, 
elongation/shrinkage, all versus temperature, including cooling phases, to be used for thermal analysis whatever the fire development,

- Quenching effect on the physical properties of structural steel and fire protection materials due to sprinklers or firefighting,

- Data on all relevant physical characteristics, as porosity, to enable modeling mass transfer in connection with heat transfer.

\section{(d) Traveling fires and non-structural elements under fire effects}

In order to model structures under fire loading, it is essential to fully understand how fires grow and spread from one compartment to another in case of several compartments or inside one large compartment (this matter is common for the 3 White Papers). The spread of fire can be significantly affected by the presence of partitions, doors, walls, fire load distributions, etc. (see also "gaps in finite element tools"). Furthermore, breaking of glass windows will affect the ventilation patterns and influence the growth and spread of a fire. New research activities must be initiated in the area of modeling non-structural elements, such as partitions, doors, walls, window breakage, etc.

\subsection{Material Experiments}

While the scope of the white paper focuses on large-scale experiments, it should be noted that experiments on material properties are required to understand and model the largerscale studies. Knowledge gaps in large-scale experiments are identified in the next section.

Standardized test methods need to be developed to obtain the necessary data on materials properties of steel elements (coupon tests) focusing mainly for the future high grades of steel, fire-resistant steels (e.g., ASTM A1077), and bridge steels such as A709 weathering (including both heating and cooling phases).

Accurate methods and standards need to be developed regarding test methods for assessing the bonding capability of fire protection systems (e.g. sprayed and intumescent material). The bonding properties of protective materials to steel need to be understood to derive the necessary thermo-physical properties that are needed for predicting the structural steel performance under fire.

\section{Topics 1 and 2: Identify and Prioritize Large-Scale Experimental Needs in Order of Importance to PBD}

Tests, at large scale and/or full scale have to be performed to provide the necessary validation data for calculation methods and to validate the simple and advanced models. Both the experiments and the models are needed to advance PBD. The subsections below identify fire-structure interaction subjects that lack full-scale testing to validate performance and modeling. We also identify tools (hybrid fire testing and sensors) that need to be tested and validated and can potentially advance large-scale testing. The research needs are listed in order of importance (i.e. the first listing being the most important). 


\section{(a) Develop advanced tools for large-scale testing}

As described previously, hybrid testing links a full structural system simulation with testing of a component of the structure in the lab. The simulation and experiment communicate with each other so that, for example, the proper boundary conditions are applied in the tests. This kind of testing has the potential to reduce costs associated with testing full systems, and although it is advanced and proven for seismic testing, only limited work has been done for fire simulations. There is a need to develop and validate (a1) hybrid fire testing for single events (only a fire), but it is also potentially a powerful tool (a2) for multi-hazard events as well (e.g., fire following earthquake or blast).

There is a need to develop (a3) new sensor technology for quantifying physical behavior up to $800^{\circ} \mathrm{C}$. Sensors and measurements of interest include strains, displacements, load cells, heat flux, and optical techniques. These types of information are crucial for calibrating and verifying complex analysis models.

\section{(b) Perform large-scale steel frame tests on 3D structural systems}

The largest absence of data is in large scale 3D structural system tests. These tests are important to complement the smaller scale tests that assume boundary conditions and cannot capture the response of the adjacent structure. Examples of large scale 3D structural system to be tested with realistic fire scenarios, that are needed to validate models and advance PBD include the following: (b1) multi-story steel framed structure with semi-rigid beam-to-column connections, (b2) braced composite frame with beamto-column hinge connections; with a set up different to the building tested in Cardington, (b3) mixed structure with high-rise steel frames and concrete core, (b4) multi-hazard of steel (and composite) structures (fire following explosion or earthquake), (b5) integrated floor system structure with different types of connections with vertical elements, (b6) tensioned-cable supported large span structure, (b7) specimens built with high grades of steel, and with "bridge" steels or fire-resistant steels, (b8) integrated floor systems (steel decking slabs with both steel and composite beams) supported by steel columns, (b9) steel structures with envelope elements such as steel roofing or façade.

\section{(c) Perform large-scale tests on structural components}

Large scale tests to be performed (for both standard and "real" fire conditions) on structural components for which there is a lack of knowledge are, e.g.: (c1) composite columns with non-uniform heating conditions over the cross-section, (c2) mega composite columns with steel profiles encased in concrete for super-tall buildings, (c3) different types of connection for composite elements, as composite beams, composite columns, (c4) buckling-restrained braces with concrete-filled steel tube, (c5) floor with fire above and with fire on both sides, (c6) protected steel and composite elements with, e.g., intumescent material, (c7) hybrid beams (welded beam with different grades of steel for web and flanges), (c8) cellular (castellated) beams.

\section{(d) Deep plate girders and long span truss beams}

Large open spaces in buildings often require (d1) deep steel plate girders (regarding, e.g., plate buckling mechanism) or (d2) long span truss beams. Also, these plate girders or truss beams could be used for column transfer. Yet little or no information exists on how 
they respond in a fire. Deep plate girders are in particular susceptible to web shear buckling. Some studies have been done on this phenomenon at high temperature [8486], mostly as applied to bridges; but there is still a need for experiments (d1) to be performed on girders deeper than $60 \mathrm{~cm}$.

\section{(e) Effect of structural response on non-structural elements}

The response of non-structural elements such as active and passive fire protection systems, doors, ducts, dampers, fire stops, etc., will affect the fire spread and effectiveness of egress. The large deformations experienced in a steel framed structure could affect the response of these non-structural systems. In addition, if the structure is designed for large seismic activity, the structural design is such that large displacements and ductility is expected. This is at odds with the design of separating and fire stop elements that cannot withstand large displacements/ductility. Full-scale testing of steel frames (e1) can address these issues to provide data on maximum deformation allowed on non-structural elements and to provide knowledge for modeling such behavior of nonstructural elements.

\section{Topic 3: Needed Research in a Timeline}

A timeline is presented below for the near term (less than 3 years), medium term ( 3 to 6 years) and long term (6 to 9 years). Before large-scale 3D structural system tests can be performed, we need to advance the tools (e.g., hybrid testing and sensors) so that proper measurements can be made. This can be done in the first three years. Simultaneous to this, large-scale tests on structural components and deep plate girders can be done with the available tools. Once advanced tools are developed, large scale 3D structural system tests can be done in the medium/long term. Incorporated in these tests (as a piggy-back) can be the non-structural element tests. However, large scale experimental is not an end in itself, but is incorporated in the process described in Section 8 (Topic 6).

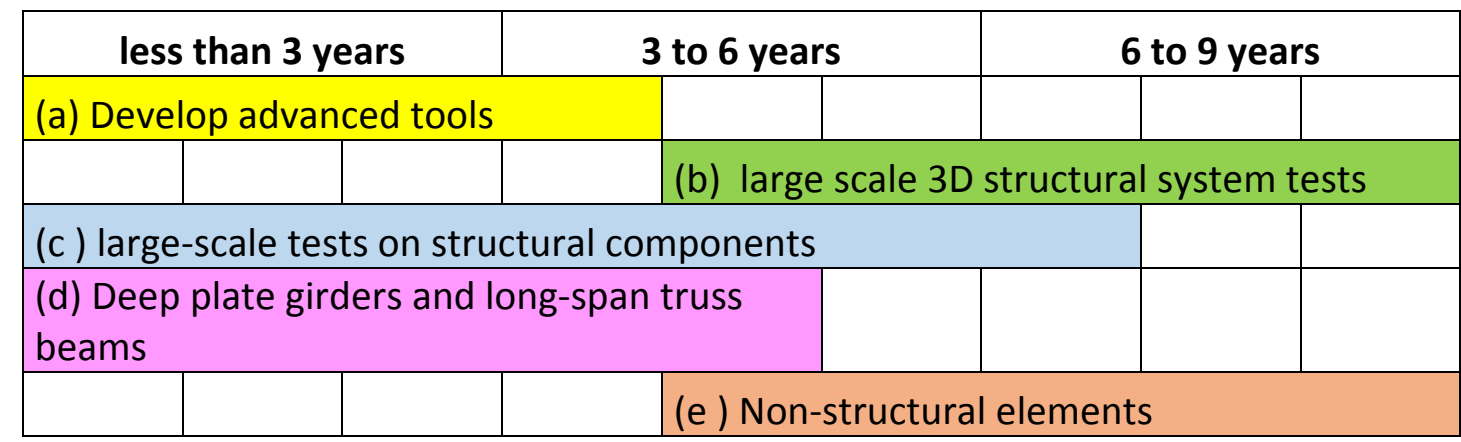

\section{Topic 4: Laboratory Facilities Available to Address Each Need}

The following laboratory facilities are suggested by the authors of the current White Paper for consideration, but without any specific contact with the given labs:

- Architecture \& Building Research Institute (Taiwan): a1, a2, c1, c3, c7, c8, d1, d2

- BAM, Berlin (Germany): a1, a2, a3, c2, c3, c4

- Braunschweig University (Germany): b7, b8, c5, c6, c7, d1, e1 
- $\quad$ BRE - FRS (UK): b2, b3

- BRI (Japan): a1, a2, c1, c2, c3, c6, c7, d1, d2

- CSTB, Champs-sur-Marne (France): b1, b6, c1, c6, d1, e1

- Efectis - Maizières-lès-Metz (France): b1, b5, b6, b8, c2, c3, c4, c5, c6, c7, d1, e1

- Lehigh University (USA): a1 $\rightarrow \mathrm{a} 3, \mathrm{c} 1 \rightarrow \mathrm{c} 6$, d1

- Michigan State University (USA): a1 $\rightarrow$ a3, c1 $\rightarrow \mathrm{c} 6, \mathrm{~d} 1$

- NIST lab (National Fire Research Laboratory) (USA): b1, b2, b3, b4, b8, b9, c1, d1, e1

- NRC, Ottawa, (Canada): a1, a2, a3, b8

- TFRI, Tianjin (China): b1, b2, b3, b8, c1, c4, c5

- Tongji University, Shanghai (China): b3, b6, c1, c2 c3, c4, c5, c6, c7

- TUS (Japan): a1, c1, c3, c6, c7, d1, d2

- University of California San Diego (USA): a2

\section{Topic 5: Potential Collaborators and Sponsors for Each Need}

Potential collaborators are national research institutes with knowledge and interests on steel structures and fire behavior, such as: CTICM - France and NRC Canada. In addition, universities and their affiliated experts are potential collaborators.

Potential sponsors are national research institutes funded by the steel construction manufacturers or by national government and steel producers, such as: AISC, AISI, ArcelorMittal, China Construction (Group) Company, European Research Fund for Coal and Steel (RFCS), Tata.

\section{Topic 6: Transfer of Results}

To be efficient, each research project should be structured as follows:

- Bibliographical study on available knowledge on the item to be tackled and identification of existing test results dealing with the item.

- If test results for the item of study are unavailable or not detailed enough, tests should be performed to cover the various expected conditions regarding the topic of the project. A database containing all detailed experimental results should be set up.

- Based on the physical phenomena identified, develop a calculation method to reproduce them and provide answers to the research item.

- Check, and if necessary improve, the accuracy of the calculation method with results of new tests to be performed. 
- Then either use the calculation method to design/verify structure according to the item covered, or use the calculation method for sensitivity analysis to provide simple calculation method dealing with the item.

- Produce report for the use of the calculation method, giving boundary limits for validity.

- Produce report for simple design method or develop standard on the same matter.

\section{Topic 7: Means to Review Progress and Exchange Information}

To review progress, a progress update sheet as shown below can be located in a web site and updated regularly (but no less than twice a year). Links to all results, especially test data, and supporting documentation should be included on the website.

\begin{tabular}{|l|l|l|l|l|l|l|}
\hline $\begin{array}{l}\text { Project } \\
\text { Number }\end{array}$ & Purpose & $\begin{array}{l}\text { Interested } \\
\text { institutes }\end{array}$ & $\begin{array}{l}\text { Interested } \\
\text { laboratories }\end{array}$ & $\begin{array}{l}\text { Interested sponsors } \\
\text { (and amount of } \\
\text { financial support) }\end{array}$ & $\begin{array}{l}\text { Progress in } \\
\text { the research } \\
\text { work }\end{array}$ & $\begin{array}{l}\text { Progress in } \\
\text { the transfer } \\
\text { of results }\end{array}$ \\
\hline 1 & & & & & & \\
\hline 2 & & & & & & \\
\hline
\end{tabular}

\section{References}

[1] Kodur, V.K., Garlock, M.E.M., Iwankiw, N. (2012). "Structures in Fire: State-of-theArt, Research, Training Needs", Fire Technology, Vol. 48, Issue 4, pp 825-839.

[2] Kathleen H. Almand (2012). "Structural Fire Resistance Experimental Research Priority Needs of U.S. Industry" NFPA - Fire Protection Research Foundation.

[3] J. Kruppa, G. Sedlacek et al. (2008). "Needs to achieve improved fire protection as regards the implementation and development of the EN Eurocodes", JRC/European Commission, EUR 23523 EN.

[4] Li G-Q, Wu B, Jiang S-C (2010). "State-of-the-art and Suggestion of Research on Fire-Resistance of Structures", Journal of Progress in Steel Building Structures, 12(5), pp13-18, 2010. (in Chinese).

[5] ISO 834-1 (1999). Fire-Resistance Tests - Elements of Building Construction - Part 1: General Requirements, Geneva - ISO.

[6] American Society for Testing and Materials (ASTM). (2000). "Standard test methods for fire tests of building construction and materials", E 119, ASTM, 1-21.

[7] Babrauskas V., Williamson R. B.(1978). "Historical Basis of Fire Resistance Testing" Fire Technology, Vol 14, No 3/Aug 1978 (part I) and No 4 / Nov 1978 (part II).

[8] ISO 23932, Fire safety engineering - General principles - Geneva - ISO - 2009.

[9] J. Kruppa, D. Joyeux (1998). "Proposal for a Real Performance Based Code in Fire Resistance", Eurofire.

[10] ISO TS 16733 (2006). Fire safety engineering — Selection of design fire scenarios and design fires - Geneva - ISO - 2006.

[11] CIB W14 (2001). Rational Fire Safety Engineering Approach to Fire Resistance of Buildings, publication 269.

[12] ISO TS 24679 (2009). Fire safety engineering - Performance of structures in fire.

[13] J. Kruppa (2010). "Eurocodes For Fire Safety Engineering”, Conference "Code in structural Engineering" - IABSE - Dubrovnik May 3-5. 
[14] EN1991-1-2: Eurocode 1: Actions on structures - Part 1-2: General rules - Actions on structures exposed to fire, Brussels, CEN, 2002.

[15] EN1993-1-2: Eurocode 3: Design of steel structures - Part 1-2: General rules Structural fire design, Brussels, CEN, 2005.

[16] EN1994-1-2: Eurocode 4: Design of composite steel and concrete structures - Part 1-2: General rules - Structural fire design, Brussels, CEN, 2005.

[17] ATC (2004). "Engineering Design Parameters for Structural Framing Systems", ATC-58 Project Task Report, Phase 2, Task 2.2.

[18] Ellingwood, B. (2009). "Ch3, Decision Framework for Fire Risk Mitigation” in Best Practice Guidelines for S.F.R of Concrete and Steel Buildings (Draft for Public Comments), NISTIR 7563, NIST, Gaithersburg, MD.

[19] Elhami Khorasani, N., Garlock, M.E.M., Gardoni, P. (2013). "Fire Load: Survey Data, Recent Standards, and Probabilistic Models for Office Buildings", Engineering Structures, Elsevier, in press: https://doi.org/10.1016/j.engstruct.2013.07.042.

[20] Sanctis, G. De, Fischer, K.; Kohler, J.; Fontana, M.; Faber, M.H. (2011). “A probabilistic framework for generic fire risk assessment and risk-based decision making in buildings" Proceedings of the 11th Int. Conf. on Applications of Statistics and Probability in Civil Engineering, p 2000-2007.

[21] Shi, Kaihan, Guo, Qianru; Jeffers, Ann (2013). "Stochastic analysis of structures in fire by Monte Carlo simulation”, Journal of Structural Fire Engineering, v 4, n 1, p 37-46, March 1, 2013.

[22] Thauvoye C. et al. (2010). "Method for calculating heat fluxes from a warehouse fire SFPE, 8th International Conference on Performance-Based Codes and Fire Safety Design Methods, Lund, Sweden 16-18 June.

[23] J.Y. Richard Liew, and Hong Chen (2004). "Explosion and Fire Analysis of Steel Frames Using Fiber Element Approach”, Journal of Structural Engineering, 130 (7), pp991-1000, 2004.

[24] J.Y. Richard Liew (2008). Survivability of steel frame structures subject to blast and fire, Journal of Constructional Steel Research Vol.64, p.854-866.

[25] Della Corte, G, Landolfo, R, Mazzolani, FM. (2003). "Post-earthquake fire resistance of moment resisting steel frames," Fire Safety Journal, 38:593-612.

[26] Scawthorn, C, Eidinger, J.M., and Schiff, A.J. (2005). Fire Following Earthquake, Technical Council on Lifeline Earthquake Engineering, Monograph No. 26, Published by ASCE, January.

[27] Scawthorn, C. (2008). "The Shake Out Scenario - Fire Following Earthquake" Prepared for United States Geological Survey, Pasadena, CA and California Geological Survey, Sacramento, CA, March 3.

[28] Lee, S., Davidson, R., Ohnishi, N., and Scawthorn, C. (2008). "Fire Following Earthquake-Reviewing the State-of-the-Art of Modeling." Earthquake Spectra: November 2008, Vol. 24, No. 4, pp. 933-967.

[29] Mousavi, S., Bagchi, A., Kodur, V.K.R. (2008). "Review of post-earthquake fire hazard to building structures", Canadian Journal of Civil Engineering, v 35, n 7, p 689-698, July 2008.

[30] Yassin H., Iqbal, F., Bagchi, A., and Kodur, V.K.K.R. (2008). "Assessment of Postearthquake Fire Performance of Steel-Frame Buildings", Proceedings of the 14th 
World Conference on Earthquake Engineering, October 12-17, 2008, Beijing, China.

[31] Neal, M., Garlock, M.E.M., Quiel, S.E., Marjanishvili, S. (2012). "Effects of Fire on a Tall Steel Building Designed to Resist Progressive Collapse", Proceedings of the ASCE Structures Congress, ASCE, Chicago, March.

[32] Quiel, S.E. and Marjanishvili, S. (2012). "Fire Resistance of a Damaged Steel Building Frame that has been Designed to Resist Progressive Collapse," Journal of Performance of Constructed Facilities, Vol. 26, No. 4, pp. 402-409.

[33] Franssen J.-M. (2005). "SAFIR: A thermal/structural program for modeling structures under fire." Engineering Journal, AISC, 42(3), pp. 143-158.

[34] http://www.vulcan-solutions.com/software.html

[35] http://www.ansys.com/

[36] Craveur J.C., Jetteur Philippe (2009). "Numerical simulation of fire resistance of ship steel decks" NAFEMS - Benchmark - July.

[37] ABAQUS version 6.8 Documentation, DS-Simulia, 2008.

[38] International Building Code (2012). International Code Council, Suite 600, 5203 Leesburg Pike, Falls Church, VA 22041.

[39] S. Kuma, B. Zhao et al.(2008). "Integrating advanced three-dimensional modelling methodologies for predicting thermo-mechanical behaviour of steel and composite structures subjected to natural fires" European Commission - EUR $23200 \mathrm{EN}$.

[40] LI G.Q. and WANG P.J. (2013). Advanced analysis and design for fire safety of steel structures, Zhejiang University Press, Hangzhou and Pringer-Verlag, Berlin Heidelberg, 2013.

[41] Yu, Xiaojun, Jeffers, Ann E. (2013). "A comparison of subcycling algorithms for bridging disparities in temporal scale between the fire and solid domains", Fire Safety Journal, v 59, p 55-61.

[42] Joël Kruppa, Daniel Joyeux, Bin Zhao (2005). " Scientific Background to the Harmonization of Structural Eurocodes" Heron (NL) VOLUME 50, No. 4.

[43] CECS200 (2006). Code for Fire Safety of Steel Structures for Buildings. China.

[44] Dwaikat, M.M.S., Kodur, V.K.R., Quiel, S.E., Garlock, M.E.M., (2011). "Experimental Behavior of Steel Beam-Columns Subjected to Fire-Induced Thermal Gradients", Journal of Constructional Steel Research, Elsevier, v67, n 1, p $30-38$.

[45] Garlock, M.E.M. and Quiel, S.E. (2007). "Mechanics of Wide-Flanged Steel Sections with Thermal Gradients Due to Fire Exposure," International Journal of Steel Structures, Korean Society of Steel Construction, 7(3), 153-162.

[46] Garlock, M.E.M. and Quiel, S.E., (2008). "Plastic Axial Load - Moment Interaction Curves for Fire-Exposed Steel Sections with Thermal Gradients", Journal of Structural Engineering, ASCE 134(6).

[47] Quiel, S.E., Garlock, M.E.M., Paya-Zaforteza, I. (2011). "Closed-form Procedure for Predicting the Capacity and Demand of Steel Beam-Columns under Fire", Journal of Structural Engineering, ASCE, 137(9), p.967-976.

[48] Agarwal, Anil, Choe, Lisa; Varma, Amit H. (2014). "Fire design of steel columns: Effects of thermal gradients", Journal of Constructional Steel Research, v 93, p 107-118, February. 
[49] Lawson R M , Mullett D L and Rackham (1997). Design of asymmetric slim floor beam using deep composite decking, SCI Publication 175, The Steel Construction Institute, Ascot, UK.

[50] Mullett D L and Lawson R M (1999). Design of slimflor fabricated beam using deep composite decking, SCI Publication 248, The Steel Construction Institute, Ascot, UK.

[51] J. M. Aribert, Ch. Renaud and B. Zhao (2008). "Simplified fire design for composite hollow-section columns", Proceedings of the Institution of Civil Engineers Structures \& Buildings 161 December Issue SB6, Pages 325-336.

[52] S. Desanghere (2007). "Development of A Simplified Model Aimed At Predicting External Members Heating Conditions" - Interflam.

[53] Selamet, S., and Garlock, M.E.M. (2012). "Predicting the maximum compressive Beam Axial Force during Fire considering Local Buckling", Journal of Constructional Steel Research, Elsevier, V.71, p.189-201.

[54] Bailey C.G. and Moore D.B., (2000). The structural behaviour of steel frames with composite floor slabs subjected to fire: Part 1: Theory and Part 2: Design.

[55] Vassart O. and Zhao B. (2013). "Membrane action of composite structures in case of fire", ECCS, Technical document, No.132.

[56] Li G.Q., Guo X.S. and Zhou H.S. (2007). "Modeling of membrane action in floor slabs subjected to fire", Structural Engineering, 29.

[57] Zhao B. (2011). "A new design method for calculating the fire protection of composite (steel and concrete) structures", EUROFIRE 2011 - "FSE - Trends and practical Applications" 25-27 May.

[58] Lie, T.T. (1992). Structural Fire Protection: Manual of Practice. ASCE Manuals and Reports of Engineering Practice. No. 78. American Society of Civil Engineers.

[59] Luecke, W.E., Banovic, S. and McColskey, J.D. (2011). "High-Temperature Tensile Constitutive Data and Models for Structural Steels in Fire". NIST Technical Note 1714. U.S. Department of Commerce. National Institute of Standards and Technology. November.

[60] PennDOT (2011). "Effects of Fire Damage on the Structural Properties of Steel Bridge Elements", PennDOT, April 30.

[61] Labbouz, S., Glassman, J., Garlock, M.E.M., Ricles, J. (2014). “Evaluating Weathering Steel Performance at Elevated Temperatures: The I-195 Bridge Fire Case Study", Proceedings of the 7th International Conference on Structures in Fire, Shanghai, China, June 11-13.

[62] "Fire resistance tests", part 1 - EN 1363-1 - CEN - March 1999.

[63] Zhao B. and Fraud C. (2004). "Fire resistance analysis of open car parks with composite structures under real car fire", Conference on composite construction July, South Africa.

[64] Joyeux D. (1997). "Natural fires in closed car parks - Car Fire Tests", CTICM report INC-96/294d - DJ/NB - August.

[65] Bin Zhao and Joel Kruppa (2004). "Structural behaviour of an open car park under real fire scenarios", Fire and Materials.

[66] Thauvoye C. et al. (2010). "Method for calculating heat fluxes from a warehouse fire SFPE, 8th International Conference on Performance-Based Codes and Fire Safety Design Methods, Lund, Sweden 16-18 June. 
[67] Dong Y. L., Prasad K. (2009). "Thermal and structural response of a two-story, two bay composite steel frame under fire loading", Proceedings of the Combustion Institute, 32, 2543-2550.

[68] Dong Y. L., Zhu E. C.,Prasad K., (2009). "Thermal and structural response of twostorey two-bay composite steel frames under furnace loading", Fire Safety Journal, 4.

[69] Bailey, C.G., Lennon, T., and Moore, D.B. (1999). "The behavior of full-scale steelframed buildings subjected to compartment fires." The Structural Engineer, Vol. 77, No. 8, pp. 15-21.

[70] Lennon,T., and Moore, D. (2004). Results and observations from full-scale fire test at BRE Cardington, 16 January 2003.

[71] Gille, M., Usmani, A.S., Rotter, J.M., (2002). "A structural analysis of the Cardington British Steel corner test", Journal of Constructional Steel Research, Vol. 58, No. 4, pp. 427-442.

[72] Luecke, W.E., McColskey, J.D., McCowan, C.N., Banovic, S.W., Fields, R.J., Foecke, T., Siewert, T.A., and Gayle, F.W. (2005). "Federal building and fire safety investigation of the World Trade Center disaster: Mechanical properties of structural steel." Technical Report NCSTAR 1-3D, National Institute of Standards and Technology. Available on-line at http://wtc.nist.gov.

[73] ASCE/SEI/SFPE 29-05 (2005). Standard Calculation Methods for Structural Fire Protection, Structural Engineering Institute, American Society of Civil Engineers, Reston, VA.

[74] EN 13381-4 \& 8 "test method for determining the contribution to the fire resistance of structural members: by applied protection to structural elements".

[75] EN 13381-5 "test method for determining the contribution to the fire resistance of structural members: by applied protection to concrete/profiled steel sheet".

[76] EN 13381-6 "test method for determining the contribution to the fire resistance of structural members: by applied protection to concrete filled hollow steel columns".

[77] Braxtan, N.J.L., Pessiki, S.P. (2011). "Post-earthquake Fire Performance of Sprayed Fire Resistive Material on Steel Moment Frames". Journal of Structural Engineering, ASCE, 137(9), p.946-953.

[78] Ryder, N.L., Wolin, S.D., and Milke, J. (2002). “An Investigation of the Reduction in Fire Resistance of Steel Columns Caused by Loss of Spray-Applied Fire Protection", Journal of Fire Protection Engineering, Vol 12, February, p. 31-44.

[79] Mostafaei, H. (2009). "A Hybrid Fire-Resistance Test Method for Steel Columns, NRC-CNRC Report \# IRC-RR-292, November.

[80] Mostafaei, Hossein (2013). "Hybrid fire testing for assessing performance of structures in fire - Application" Fire Safety Journal, v 56, p 30-38, 2013

[81] Mostafaei, Hossein (2013). "Hybrid fire testing for assessing performance of structures in fire - Methodology" Fire Safety Journal, v 58, p 170-179.

[82] Correia, António M.; Rodrigues, João Paulo C.; Korzen, Manfred (2012). "Experimental research on the load-bearing capacity of partially encased steel columns under fire conditions", Journal of Structural Fire Engineering, v 3, n 1, p 81-94, March. 
[83] Henneton N., Kruppa J. and Zhao B. (2011). "Fire risk assessment for people in steel structure warehouses", EUROSTEEL, September, Budapest, Hungary.

[84] Payá-Zaforteza, I, Garlock, M. (2012). "A numerical investigation on the fire response of a steel girder bridge", Journal of Constructional Steel Research, Elsevier, V. 75, p.93-103. 59.

[85] Glassman, J., Garlock, M.E.M. (2014). "Shear buckling behavior of steel plate girders at elevated temperatures", Proceedings of the ASCE Structures Congress, ASCE, Pittsburgh, PA, May.

[86] Glassman, J., Garlock, M., (2014). "Elevated temperature evaluation of an existing steel web shear buckling analytical model." Accepted for publication in Journal of Constructional Steel Research, Elsevier.

[87] T. Kitano, O. Sugawa, H. Masuda, T. Ave \& H. Uesugi, (2000). "Large Scale Fire Tests of 4-Story Type Car Park (Part 1: The behavior of structural frame exposed to the fire at the deepest part of the first floor)", Proceedings of the Fourth AsiaOceania Symposium on Fire Science and Technology, May.

[88] Hirashima, T., Wang, Y. and Uesugi, H., (2003). "Large Scale Fire Tests Of A 4story Type Car Park Part 2 Analysis Of The Thermal Stresses And Deflections" Fire Safety Science 7: 655-666. doi:10.3801/IAFSS.FSS.7-655.

[89] Chen-Hung Lee, Yaw-Jeng Chiou, Hsin-Yang Chung, Chien-Jung Chen (2011). "Numerical modeling of the fire-structure behavior of steel beam-to-column Connections" Journal of Constructional Steel Research Vol.67 p.1386-1400.

[90] Hsin-Yang Chung, Chen-Hung Lee, Wun-Jie Su, Rih-Zeng Lin (2010). "Application of fire-resistant steel to beam-to-column moment connections at elevated temperatures", Journal of Constructional Steel Research Vol. 66, p. 289-303.

[91] Kuo-Chen Yang, Sheng-Jin Chen, Ming-Chin Ho (2009). "Behavior of beam-tocolumn moment connections under fire load", Journal of Constructional Steel Research, Vol. 65, p.1520-1527.

[92] Pakala, P., Kodur, V., Selamet, S., and Garlock, M.E.M. (2012). "Fire behavior of shear angle connections in a restrained steel frame", Journal of Constructional Steel Research, Elsevier, Volume 77, Pages 119-130.

[93] Buick Davison, J.; Burgess, Ian W.; Plank, Roger J.; Yu, Hongxia; Hu, Yin (2010). "Ductility of simple steel connections in fire", Proceedings of SDSS' Rio 2010: International Colloquium Stability and Ductility of Steel Structures, v 1, p 441448.

[94] Guanyu Hu; Engelhardt, M. (2012). "Studies on the Behavior of Steel Single-Plate Beam End Connections in a Fire", Structural Engineering International, v 22, n 4, p 462-9, Nov. 2012.

[95] Selden, K., Fischer, E., Varma, A. (2012). "Experimental Evaluation of Composite Beams Subjected to Fire Loading", Proceedings of the 7th International Conference on Structures in Fire, Shanghai, China, June 11-13. 